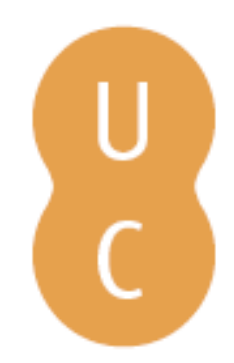

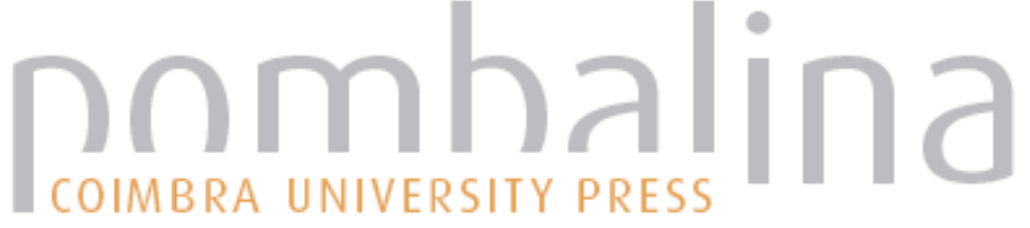

\section{Da deontologia do jornalismo à ética da informação}
Autor(es):
Cornu, Daniel
Publicado por: Imprensa da Universidade de Coimbra
URL
persistente:
URI:http://hdl.handle.net/10316.2/36646
DOI:
DOI:http://dx.doi.org/10.14195/978-989-26-0873-0_7

Accessed : $\quad$ 26-Apr-2023 15:17:03

A navegação consulta e descarregamento dos títulos inseridos nas Bibliotecas Digitais UC Digitalis, UC Pombalina e UC Impactum, pressupõem a aceitação plena e sem reservas dos Termos e Condições de Uso destas Bibliotecas Digitais, disponíveis em https://digitalis.uc.pt/pt-pt/termos.

Conforme exposto nos referidos Termos e Condições de Uso, o descarregamento de títulos de acesso restrito requer uma licença válida de autorização devendo o utilizador aceder ao(s) documento(s) a partir de um endereço de IP da instituição detentora da supramencionada licença.

Ao utilizador é apenas permitido o descarregamento para uso pessoal, pelo que o emprego do(s) título(s) descarregado(s) para outro fim, designadamente comercial, carece de autorização do respetivo autor ou editor da obra.

Na medida em que todas as obras da UC Digitalis se encontram protegidas pelo Código do Direito de Autor e Direitos Conexos e demais legislação aplicável, toda a cópia, parcial ou total, deste documento, nos casos em que é legalmente admitida, deverá conter ou fazer-se acompanhar por este aviso.

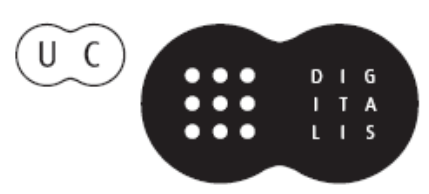


www.uc.pt/ imprensa_uc CONTACTO imprensa@uc.pt VENDAS ONLINE http://livrariadaimprensa.uc.pt JANEIRO 2015
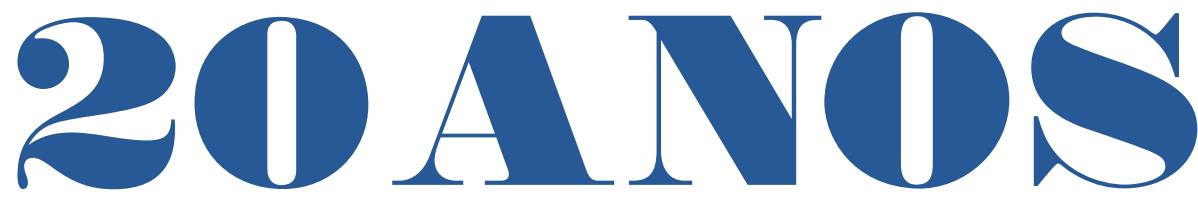

\section{DE JORNALISMO CONTRA A INDIFERENÇA}

TEXTOS DE

Marc Lits, Adriano Duarte Rodrigues, Tito Cardoso e Cunha, José Augusto Mourão, Alberto Pena Rodríguez, Maria Augusta Babo, Daniel Cronu, João Pissarra Esteves, Gilles Gauthier, Heloísa Paulo e Luís Reis Torgal, Alfredo Barroso, António Fidalgo, Nöel Nel, João de Almeida Santos, Juan Luis Cebrián, António Dias Figueiredo, Marina Themudo, Jorge Sampaio, Nelson Traquina, Mário Soares
( livro que agora se apresenta, nasce de dois desígnios fundamentais: por um lado, celebrar duas décadas de ensino do Jornalismo na Universidade de Coimbra e, por outro, partilhar com um público mais alargado um conjunto de reflexões sobre os media, o jornalismo, a comunicação e o espaço público.

Se o ensino superior do Jornalismo em Portugal, relativamente tardio em relação ao resto da Europa, deu os seus primeiros passos no fim dos anos 70 do século passado, ele aparece apenas duas décadas depois na academia coimbrã. Contudo, esta foi, no contexto nacional, a primeira licenciatura em Jornalismo, distinguindo-se, quer em título, quer em objetivos, das licenciaturas então existentes no país. A criação de uma Licenciatura em Jornalismo na Universidade de Coimbra, em 1993-1994, foi, por si, um acontecimento. Com efeito foi necessário que reitor, professores e jornalistas ousassem atualizar a oferta curricular da Faculdade de Letras, oferecendo um curso há muito desejado pela sociedade e pelo mercado, embora desconsiderado por alguns setores da academia. Correndo o risco de omitir alguém, a quem antecipadamente pedimos desculpa, não podemos deixar de recordar os esforços dos jornalistas João Mesquita, João Fonseca, em representação
Todas as gerações, sem dúvida, se julgan para refazer o mundo. A minha sabe, nc que não poderá refazê-lo. A sua tarefa é tc

Consiste em impedir que se desfaça, $p$ unicamente das suas negações A. Camus, Discursos da Suécia (1957)

do Sindicato dos Jornalistas, e de Jorge Castilho, a quem mais tarde se viria associar o nome de Mário Martins, bem como o do então Reitor da Universidade de Coimbra Rui Alarcão, e dos professores João Roque e Luís Reis Torgal. Entre 1993 e 1996, a Licenciatura em Jornalismo funcionou com um Secretariado, que teve um papel executivo e científico nos primeiros tempos do curso na FLUC. Presidido pelo Presidente do Conselho Científico Ludwig Scheidl, este 


\title{
Da deontologia do jornalismo à ética da informação
}

\author{
Daniel Cornu \\ Mediador do Grupo Suíço Tamedia
}

Faltam referências às sociedades modernas. $\mathrm{O}$ apagamento do religioso priva-as dos seus antigos fundamentos. O desmoronamento das ideologias esvazia-as de projetos. Sem transcendência e sem utopias, elas procuram critérios e valores que possam ser partilhados. Estaremos perante a era do vazio'? Seria mais exato falar de incerteza e de confusão. A desordem contemporânea provoca uma reação análoga às reações da física, como um caos que estaria em busca da sua ordem. Nunca as questões relativas à ética se colocaram com tanta premência.

São múltiplos os indícios deste regresso. Os mais variados domínios da atividade do homem são hoje atravessados por questões éticas. Os mais visíveis são sem dúvida o mundo científico e o mundo médico, que se debatem com as novas questões colocadas pelos progressos obtidos no conhecimento da vida, pela capacidade de intervenção nos processos vitais. O mundo económico também é atravessado por interrogações sobre as práticas de negócios, as condições da produção industrial, as relações humanas no seio da empresa, a gestão dos recursos naturais. Numerosas profissões liberais já criaram familiaridade com a ética, mas hoje em dia outras profissões já se confrontam com ela. ${ }^{2}$

\section{A ética da informação}

Não é pois surpreendente que as questões éticas digam igualmente respeito ao jornalismo e aos media, cuja importância na vida das sociedades contemporâneas já não necessita de ser demonstrada: a visitação dos media representa nas sociedades ocidentais a terceira ocupação do homem moderno, depois do trabalho e do sono. Ora esta visitação não é passiva. Se as questões da ética da informação interessam aos seus principais atores, os jornalistas, eles dizem plenamente respeito ao público. Este inquieta-se com

\footnotetext{
"Conferência proferida na Faculdade de Letras da Universidade de Coimbra. Trad. portuguesa de Ângela e José Carlos Bernardes.

${ }^{1}$ Gilles Lipovetsky, L'Ére du Vide. Essais sur l'individualisme contemporain, Paris, Gallimard, 1983.

${ }^{2}$ Alain Etchegoyen, La Valse des étiques, Paris, François Bourin, 1991.
} 
as disfunções, os desvios, as derrapagens, as faltas que lhe parecem incompatíveis com o conceito ou com os conceitos, que ele pode ter sobre o papel dos media na sociedade e sobre a liberdade que lhes é concedida.

A ação dos media cobre um campo extremamente vasto, em razão da própria diversidade das funções que lhes são reconhecidas. Os média preenchem a missão da imprensa tal como ela é definida de forma clássica nos países de tradição democrática e liberal, a saber, fornecer ao público opiniões e informações bastante numerosas e variadas, de forma a permitirem que ele forme a sua opinião própria. Além disso desempenham outras funções, de carácter educativo, participando na difusão do conhecimento e sobretudo de divertimento. Para além disso, os meios de comunicação de massas são tidos por agentes de coesão social. Eles favorecem, pela mediatização de conteúdos comuns, a inserção do indivíduo no seu grupo social, conferindolhe instrumentos de compreensão e de identificação. Este contributo para o reforço dos laços sociais confirma que os media são responsáveis pelas preocupações de um coletivo que se procura compreender a si próprio, por indivíduos que aí tentam encontrar o seu lugar e se interrogam sobre o seu relacionamento, não apenas com o poder em sentido político, mas com o conjunto dos grandes sistemas sociais.

Interrogar-se sobre a ética do jornalismo e sobre a sua relação com a ética dos media é aceitar não reter, de entre as múltiplas ações dos media, apenas os aspectos ligados à função de informar. Ela é portanto bastante complexa para justificar uma reflexão específica.

Na sua aceção mais corrente, que aqui acolhemos, a informação recolhe o conjunto de factos da atualidade que os media levam ao conhecimento do público. Compreende as opiniões emitidas a seu propósito pelos diversos atores sociais, bem como os comentários, os pontos de vista das redações. No seio dos media a informação é uma questão específica dos jornalistas e dos outros profissionais diretamente implicados na definição intelectual da sua forma e do seu conteúdo. Ela é pois elevada ao primeiro nível da responsabilidade individual e coletiva das redações.

\section{A ética, a moral e a deontologia}

O que deveremos entender por ética? As relações entre a ética, a moral e a deontologia não são claras e devem ser precisadas a cada momento.

Os termos moral e ética são empregados de forma indistinta por numerosos autores. Não sem razão, uma vez que ambos remetem, o primeiro pela sua raiz latina, o segundo pela sua raiz grega, aos hábitos. A observação em- 
pírica das utilizações atuais leva, por outro lado, a constatar um recurso bastante mais frequente ao tema ética sem que o seu conteúdo seja distinguido do da moral. A ética poderia, assim, não ser mais do que uma formulação moderna da moral, religiosa ou laica, que ainda orientaria a educação e que influenciaria os manuais escolares durante a primeira metade do século.

As regras morais ou éticas não têm necessariamente de ser distinguidas, uma vez que elas significam um conjunto definido de regras necessárias para orientar a ação humana, qualquer que ela seja. Basta mencionar os outros tipos de preceitos para que as regras morais ou éticas surjam na sua especificidade comum: o conselho, a recomendação, a ordem. Estes preceitos assinalam, por defeito, a particularidade das regras morais ou éticas. Estas últimas passam, de facto, por um processo no interior do indivíduo, de deliberação, de aceitação ou de rejeição. A escolha moral ou ética opera, não tendo em vista uma seleção de meios técnicos nem em função de um objetivo de carácter pragmático, mas sim em resposta a imperativos ligados aos primeiros fundamentos ou aos fins últimos, expressos por valores.

O discurso contemporâneo sobre a moral e sobre a ética, no entanto, continua a ter lugar para distinções entre os dois termos. Estas distinções correspondem a dois modelos, entre os quais a escolha se opera frequentemente por simples convenção.

O primeiro destes modelos remete para uma aceção clássica. A moral é a instância primeira, ela é reconduzida a um conjunto de preceitos no fundamento da ação dos homens e das relações entre os seres humanos, à qual o indivíduo aceita submeter-se para viver em sociedade. Ela aspira ao absoluto, ao universal. A ética é portanto compreendida como a assunção pessoal de um conjunto de valores livremente adotados por um indivíduo, em função do fim que este se propõe a si mesmo. Ela surge como subsidiária. Esta conceção recupera a diferença que estabelece o filósofo Paul Ricoeur entre "o que é considerado bom" (a ética) e "aquilo que se impõe como obrigatório" (a moral)3.

Segundo este mesmo modelo, a distinção entre moral e ética pode ser igualmente entendida como uma expressão da diferença entre os preceitos gerais e os preceitos próprios de um determinado campo de atividade.

${ }^{3}$ Paul Ricoeur, Soi-même comme un autre, Paris, Seuil,1990, p. 200. Esta posição reconduznos a uma herança aristotélica, em que a ética é caracterizada pela sua perspetiva teleológica (o fim da ação), e a uma herança Kantiana, onde a moral é definida pelo carácter obrigatório da norma (o fundamento da ação), na qual Ricoeur lê um ponto de vista deontológico (fundado sobre a noção de dever). 
O termo moral designa então "os valores e os princípios mais elevados e mais gerais relativamente à orientação das ações humanas” enquanto o termo ética está reservado para "os subconjuntos que regem ou que pretendem regular os diversos domínios da atividade humana”. Dentro desta perspetiva, o termo deontologia - que ignora a utilização moderna tanto em inglês como em alemão - designaria as regras de colocação em prática de uma ética "no campo de aplicação que lhe é próprio", ética aplicada a um grupo, a uma profissão, no caso entre os media e os jornalistas ${ }^{4}$.

Este primeiro modelo pode levar a desqualificar a ética quando esta entra em conflito com a moral ou quando pretende tomar o lugar da moral. Desta forma, para Alain Etchegoyen, "as éticas substituiram-se à moral, como um sucedâneo", tendo como consequência que o indivíduo, privado das antigas referências comuns da moral, se encontra dividido entre as diversas esferas de aplicação da ética, "apanhado numa valsa de éticas ao ritmo dissonante de partituras heterogéneas”.

Esta visão crítica corresponde, em grande parte, à realidade do momento atual. O termo ética é muitas vezes utilizado desordenadamente. Designa as práticas que são supostas ocupar o lugar deixado vago pelo apagamento das normas morais. A ética, neste sentido, tende a orientar-se para fins pragmáticos, ela cede às formas mais cómodas de utilitarismo. Perde em força normativa, em perenidade, em universalidade, o que ganha em souplesse, em capacidade de adaptação, em faculdade de resposta a situações concretas, em eficácia estratégica. Ensinamos nas escolas de gestão que "a ética compensa”. Confiamos a comissões ad hoc o cuidado de a formular, tendo por objetivo principal tranquilizar o cliente ou o utilizador.

Os jornalistas clamam a sua exigência ética sempre que sentem a necessidade de restaurar a sua imagem. Os media impõem-se a si próprios códigos de conduta sempre que receiam pela sua credibilidade, possuídos pelo sentimento de que muitas derrapagens poderiam incitar o público a descrer deles. O mundo da comunicação está permanentemente agitado por colóquios, debates, discussões sobre códigos ou cartas, procurando regular uma atividade relativamente à qual cada um tem o seu próprio entendimento sobre o lugar que essa atividade ocupa na vida quotidiana e o afastamento das normas que são supostas dirigi-la.

${ }^{4}$ Denis Huisman, L'Age du faire. Pour une morale de la communication, Paris, Hachette, "Pluriel", 1994, p. 12.

${ }^{5}$ Op. cit., pp. 14-15. 
O segundo modelo de relações entre a moral e a ética apresenta uma aceção relativa da moral. É isso que resulta da definição muito ampla que dela dá o Vocabulaire téchnique et critique de la philosophie: conjunto das prescrições admitidas numa determinada época e num determinado local, o esforço para cada um se conformar a essas prescrições, a exortação a segui-las". Quanto à ética, ela é definida como "a ciência que tem por objeto o juízo de apreciação enquanto este se aplica à distinção entre o bem e o mal” ${ }^{6}$. A ética caracteriza-se, portanto, por uma exigência de sistematização, por um projeto crítico. Se a moral enuncia os fundamentos, a ética conduz a uma interrogação sobre estes mesmos fundamentos.

Este é o ponto de vista que adota Jacqueline Russ, em La Pensée éthique contemporaine: "A ética esforça-se por desconstruir as regras de conduta que formam a moral, os juízos de bem e de mal que se unem no seio desta última. (...) ela enfraquece as estruturas e desmonta a edificação, para se esforçar a descer até aos fundamentos ocultos da obrigação" . Coincide com a conceção defendida por outros autores contemporâneos ${ }^{8}$, embora estes distingam a ética normativa da meta-ética, as normas e a ultrapassagem destas normas por um questionamento crítico. Coincide também com a tentativa de distinguir, num domínio ético-moral indiferenciado, as funções de regulação e de legitimação.

A ética pode então ser considerada uma instância superior à moral. Aqui não se trata portanto de aplicações mais ou menos utilitaristas, mas sim de buscar os fins últimos que legitimam os próprios fundamentos morais. É por isso que a deontologia, entendida como um conjunto de deveres próprios de uma prática determinada não aspiraria, de acordo com este segundo modelo, senão a descolar da moral, da qual constituiria uma espécie de território reservado.

A justaposição destes dois modelos cria uma dificuldade semântica em todos os debates contemporâneos sobre a ética, sobretudo desde que ele se desenrole entre práticos. Como tomar em conta, desde logo, numa ética da informação, das diversas categorias identificadas até aqui: a simples referên-

\footnotetext{
${ }^{6}$ André Lalande, ed., Vocabulaire technique et critique de la philosophie, Paris, PUF, 8e éd., 1960, pp. 305-306.

7 Jacqueline Russ, La Pensée éthique contemporaine, Paris, PUF, "Que sais-je?», 1994, p.5 Encontraremos o mesmo ponto de vista, a partir da função de legitimação da ética em Jürgen Habermas, em Daniel Cornu, Jornalisme et Verité. Pour une éthique de l'information, Genebra, Labor et Fides, 1994.

${ }^{8}$ Por exemplo, Angèle Kremer-Marietti, L'éthique, Paris, PUF, «Que sais-je?», 1987.
} 
cia aos usos, a formulação das normas, a regulação das práticas, a fundação e a legitimação das normas?

\section{As quatro categorias da ética da informação}

Segundo a tradição anglo-saxónica, a apreensão da ética pode ser submetida a três níveis de análise9 . O primeiro nível, descritivo, salienta a análise sociográfica e histórica das regras morais, naquilo que elas têm de comum e naquilo que as distingue entre uma sociedade e outra, entre uma época e outra. O segundo nível, normativo, pertence à filosofia moral, procurando determinar em que consiste o Bem e o Mal, o Justo e o Injusto, visando enunciar deveres e direitos. O terceiro nível, meta-ético, salienta uma ética reflexiva, que se interroga, por um lado, sobre as questões epistemológicas, lógicas ou semânticas sobre os dois primeiros níveis e sobre as teorias que visam englobá-las e, por outro lado, ultrapassando o aspeto da crítica formal do discurso moral, sobre a legitimidade das práticas e das normas.

A estes três níveis convém juntar uma categoria que resulta já de uma reflexão crítica e que remete para a dimensão estratégica da ética. Para a situar é necessário recordar sumariamente a diferença entre duas abordagens clássicas da ética. Segundo uma abordagem fundada no dever moral, deontológico, no sentido da tentativa de Kant, a ética estabelece regras de comportamento intrinsecamente boas e justas. Segundo uma abordagem orientada para determinados fins, teleológica, a moralidade das condutas humanas é avaliada em função das suas consequências. Neste último caso, isto significa que as ações aparentemente pouco morais podem conduzir a resultados desejáveis e contribuir, por exemplo, seguindo o utilitarismo de Bentham e Mill, ao interesse bem compreendido da sociedade. Em matéria de informação, a ética estratégica reclama-se desta última abordagem: ela visa tranquilizar o público e dissuadir o poder político de intervir, através da proclamação de uma autorregulação interna à profissão; ao mesmo tempo, ela reclama-se do interesse bem compreendido, entendido, segundo uma perspetiva liberal, como a maior liberdade deixada à informação na sociedade. A ética estratégica compreende as inevitáveis derrapagens dos media como o preço a pagar para assegurar essa liberdade fundamental.

${ }_{9}^{9}$ André Gosselin, «Le champ éthique de la pratique du journalisme et du droit à l'information», Communication, vol. 13, no 1, printemps 1992, Québec, Université de Laval, Editions Saint-Martin. 
A ética da informação, pelo seu próprio enunciado, sugere o abandono do termo moral, efetivamente pouco empregado neste contexto. Um tal abandono não pode todavia ser admitido senão na condição de ser preservado aquilo que ele protege, a saber: os fundamentos primeiros da boa ação na sua aceção clássica; o conjunto das regras reconhecidas como normas no seu sentido mais moderno. Da mesma forma, podemos aceitar que recorra à noção de deontologia se queremos admitir que se trata, aplicado a um domínio particular de atividade, de um aspeto da ética para uns ou de uma forma da moral para outros.

Ao abrigo desta dupla condição estamos pois autorizados a falar de ética da informação do mesmo modo que precisamos as qualificações, que correspondem a diferentes categorias de ética ${ }^{10}$.

a. Uma ética descritiva consiste em observar e descrever as práticas da informação, num sentido próximo da própria etimologia do termo: os costumes, os usos dos jornalistas e dos media. Através da observação é possível descobrir os valores aos quais se refere a prática, sem que a referência seja necessariamente explícita. A descrição inclui por fim, num esforço relevante da psicologia social, a identificação dos constrangimentos aos quais os jornalistas estão submetidos.

b. Uma ética estratégica emana de uma abordagem utilitarista. É a forma muitas vezes abusiva que a ética assume quando visa, como primeira prioridade, dar confiança ao público e aos utilizadores, através da comunicação de uma boa imagem. É a ética profissional ou a deontologia que é ostentada, livre para responder apenas à constatação ambígua de que "a ética compensa".

c. Uma ética normativa enuncia princípios, regras e obrigações. As normas mais gerais fazem referência à moral comum, bem como ao direito comum (a proteção da pessoa humana, os atentados à honra). Os deveres específicos são enunciados em códigos de deontologia e o seu controlo é assegurado por órgãos como os conselhos de imprensa, os mediadores ou os provedores do leitor (ombudsmans). A ética normativa (ou prescritiva) assegura a regulação das práticas.

d. Uma ética reflexiva, também chamada de meta-ética, ultrapassa as outras formas de ética, e mesmo a ética normativa. Ela funciona como instância de

${ }^{10}$ Estas categorias são igualmente retomadas por Boris Libois, L'Éthique de l'information. Essai sur la déontologie du journalisme. Bruxelles, Editions de l'Université de Bruxelles, 1994. 
legitimação das práticas e das normas, bem como de colocação à prova da imagem.

As categorias da ética aplicam-se à ética da informação. Esta é constituída, de facto, por um conjunto de práticas, de discursos, de referências e de interrogações que formam uma constelação muito complexa.

Ela emerge de práticas costumeiras. Por exemplo: o hábito de citar sistematicamente as fontes de cada elemento de uma informação, de acordo com a tradição do jornalismo anglo-saxónico, de forma a indicar a sua origem e de permitir ao público avaliar da sua credibilidade; ou a regra que impõe que cada informação seja verificada junto de duas fontes, no mínimo.

Ela passa pela afirmação de posições estratégicas, quando procura justificar publicamente, em referência a valores, a uma linha editorial, a princípios gerais de programação ou a escolhas operadas caso a caso. A decisão de publicar ou de não publicar o nome de uma pessoa implicada neste ou naquele caso judicial pode ser objeto de uma tal justificação pública. Ou ainda a decisão de colocar ou não no ar imagens de violência relativas a um acontecimento de atualidade.

A ética da informação reclama-se de normas definidas em códigos deontológicos. A deontologia impõe, assim, a um jornalista que não publique uma notícia relativamente à qual ele não conhece a fonte. Impede-lhe de receber vantagens materiais ou morais se publica ou, pelo contrário, se aceita calar uma informação. Proíbe a utilização de métodos desleais para obter informações, imagens ou documentos.

A ética da informação passa finalmente pela necessária deliberação, na consciência dos jornalistas e no seio das redações, com a finalidade de legitimar uma decisão. A deliberação intervém de forma obrigatória quando se afrontam princípios concorrentes da própria deontologia. Ainda assim, o direito do público a saber, que legitima a atividade jornalística, pode revelar-se incompatível com a proteção legítima da pessoa humana.

Ninguém duvida que existem numerosos exemplos de desfuncionamento da informação. Estes podem ser explicados, no plano teórico, por uma ponderação insuficiente ou mal efetuada das relações entre as categorias da ética feita pelos próprios jornalistas. Explicam-se também, na realidade, através da existência de forças que vêm opor-se ao esforço ético dos indivíduos. Estas forças opostas estão ligadas ao caráter comercial da informação, visto que os media vendem a informação ao público, para vender depois o público aos anunciantes. Elas submetem o próprio estatuto dos jornalistas no seio das empresas mediáticas, bem como os diversos constrangimentos que estes 
sofrem, à resposta que os seus media levam até junto do público. Elas são também exercidas palas alterações tecnológicas e pelos imperativos técnicos da comunicação moderna. É por isso que uma ética da informação não se resume à ação dos seus agentes individuais mais visíveis: os jornalistas, os fotógrafos, os operadores de televisão. Ela diz respeito aos media tanto como empresas, como organizações.

Esta passagem de uma ética do jornalismo a uma ética dos media não é completamente evidente. Na tradição liberal, clássica ou moderna, a atribuição da responsabilidade recai inteiramente sobre os jornalistas, vistos como indivíduos ou como corpos profissionais. Esta situação alimenta um paradoxo duradouro, na medida em que os jornalistas, face aos comentários sobre os desvios dos media e as derrapagens da informação, invocam em sua defesa os diversos constrangimentos aos quais estão submetidos, ao mesmo tempo que invocam em sua defesa uma melhor deontologia, ela própria determinante na eliminação ou no domínio destes constrangimentos.

\section{Os constrangimentos do jornalismo}

A análise dos constrangimentos é uma etapa absolutamente necessária na definição de uma ética da informação. Ao esquecê-los correríamos o risco de condenar a ética normativa a estar dominada por regras puramente formais, sem correspondência na realidade. Um único enunciado de princípios ideais exporia os jornalistas a um duplo logro: o refúgio ilusório por detrás de uma visão mitificada da profissão, de onde cada um retiraria boa consciência; e a crença enganosa de que esta visão justificaria por si própria as suas práticas aos olhos do público. A deontologia serviria, em suma, de álibi no interior da profissão e de caução para o exterior.

O confronto com as condições reais do exercício do jornalismo, os exames dos usos e dos costumes da profissão (no sentido de uma ética descritiva) impedem, assim, o encaminhamento da ética no sentido de uma aceção de caráter puramente estratégico. Esta atualização dos mecanismos emana, em larga medida, das ciências sociais. Não tem por objetivo desencorajar os voluntários do "fazer bem", nem desesperar as consciências que aspiram a um jornalismo íntegro. Ela permite, pelo contrário, aos jornalistas "trabalhar" sobre os determinismos aos quais eles estão submetidos, de forma a definir e a explorar melhor o espaço de liberdade que é o seu. ${ }^{11}$

${ }^{11}$ Tal perspetiva resulta claramente dos trabalhos de Pierre Bourdieu sobre o campo do jornalismo: "L'emprise du journalisme", Actes de la recherche en sciences sociales, 
a. O enquadramento jurídico representa um constrangimento para o jornalismo. Mas trata-se, no sentido em que o entende Pierre Bourdieu, de um constrangimento "virtuoso": incita o jornalista a fazer bem. O reconhecimento constitucional da liberdade de imprensa, em sentido lato, legitima a atividade do jornalista. A autorregulação da profissão, por seu lado, tem largamente em conta a existência de normas jurídicas. Não se limita, portanto, ao simples respeito pelas leis, como pareceriam demonstrar os imperativos comuns a todos os códigos de deontologia sobre a proteção da vida privada e sobre os atentados à honra. Antecipa a aplicação do direito através do estabelecimento espontâneo destas normas. Ultrapassa sobretudo as exigências através de uma perceção mais positiva dos deveres. A ética da informação implica um respeito por outrem - objeto ou destinatário da informação - que não está apenas ligado a interdições ou a riscos e que, neste sentido, os completa e ultrapassa. Não exclui, em certos casos, a oposição a regras de direito em nome de princípios éticos superiores, evitando obrigar o jornalista a assumir as consequências para si próprio. É o caso da proteção das fontes confidenciais do jornalista, que não é assegurada em todos os países da mesma forma $^{12}$. Existem, portanto, entre o direito e a deontologia, grandes áreas de convergência, mas não uma coincidência total. Fazer "bom jornalismo", no sentido ético, não consiste num simples respeito pelas leis.

b. Os jornalistas vivem muitas vezes a sua atividade como se ela se tratasse de uma profissão liberal. São, na grande maioria, empregados por conta de outrem. Incluem-se numa organização, são obrigados a cumprir determinadas funções, o seu trabalho insere-se num processo de fabrico, são submetidos a relações de autoridade e de responsabilidade. Relativamente à aplicação dos deveres e dos direitos enunciados pela sua deontologia, a sua inserção numa empresa representa um feixe de constrangimentos. Essa integração obriga-os a um "compromisso permanente " entre a aplicação de normas profissionais e as exigências da empresa, que passam pela manutenção de condições de sobrevivência e se possível de desenvolvimento

n. ${ }^{\circ}$ 101/102, março 1994, Paris, Seuil; "Journalisme et éthique”, comunicação no colóquio fundador do Centro de investigação de jornalismo à Escola Superior de Jornalismo(ESJ) de Lille, 3 de junho de 1994. Nesta última ocasião, Bourdieu formulou ainda o desafio: "como reforçar os constrangimentos que poderemos chamar de "virtuosos", ou seja aqueles que conduzem à virtude, e como diminuir, ao procurá-los para os contrariar, os constrangimentos “viciosos”, ou seja aqueles que conduzem à falha ou ao erro?".

${ }^{12}$ A proteção da confidencialidade das fontes foi reconhecida como "uma das pedras angulares da liberdade de imprensa" pelo Tribunal Europeu dos Direitos do Homem (acórdão Goodwin contra Reino-Unido, de 27 de maio de 1996). 
económico ${ }^{13}$. Os constrangimentos económicos obrigam a prestar uma atenção constante aos gostos do público, a procurar tornar o produto mediático atraente para os anunciantes. Estes constrangimentos arriscam-se a introduzir uma ditadura da audiência, a busca desenfreada do "scoop" (furo jornalístico"), a deslocação do interesse público no sentido do interesse do público.

c. No interior das empresas, o trabalho jornalístico é submetido a duas forças contraditórias. Por um lado, um isolamento (em relação às outras funções incluídas na cadeia de produção) e uma fragmentação crescente das tarefas (relativamente aos outros jornalistas) não dão ao jornalista, a não ser muito raramente, o controlo total da sua "obra jornalística": este fenómeno é particularmente percetível no audiovisual. Por outro lado, uma tendência nova para a polivalência dos jornalistas pode levá-los a sacrificarem os aspetos essenciais do seu trabalho jornalístico, (a investigação, a verificação, o trabalhar das informações) para satisfazer as exigências de puro fabrico do produto mediático, dominadas pelo condicionamento formal da informação; esta tendência é cada vez mais marcante na imprensa escrita ${ }^{14}$.

Nestes dois casos, portanto, o aspeto coletivo da atividade jornalística desempenha um papel essencial. Se a ética pressupõe uma liberdade, o exercício dessa liberdade no domínio da informação raramente é solitário. O jornalista nunca está só perante as suas escolhas. Deveremos entender esta inserção num trabalho coletivo como uma perda suplementar da autonomia do jornalista? Nada impede de a considerar, pelo contrário, como um incitamento à reflexão ética, uma vez que ela assume uma responsabilidade solidária nas escolhas e no tratamento da informação. Ela justifica, por isso, a conjugação de um certo número de normas profissionais comuns, dito de outra forma, a existência de instrumentos de deontologia jornalística. Ela participa ainda nas condições de uma ética reflexiva que se interroga sobre a aplicação das normas, sobre as escolhas e as decisões da hierarquia, a fim de as submeter a uma prova de legitimação. O diálogo no interior das redações constitui, de facto,s um dos melhores meios de resistir a certos cons-

\footnotetext{
${ }^{13}$ Ver Michel Mathien, Le système médiatique. Le journal dans son environnement, Paris, Hachette, 1989, e Les journalistes et le systéme médiatique, Paris, Hachette, 1992.

${ }^{14}$ Jean-Marie Charon e Clarisse Feletin, "Le développement de la polyvalence chez les journalistes", Les Cahiers de l'Observatoire des pratiques et des métiers de la presse n. ${ }^{\circ}$, dezembro 1994, Paris, Centre de formation et de perfectionnemnet des journalistes. A polivalência atinge também os video-jornalistas, ou os jornalistas repórteres de imagem (JRI), da televisão.
} 
trangimentos contra os quais um indivíduo isolado se sentiria impotente e diminuído.

d. O jornalista encontra-se preso numa rede de relações sociais, como indivíduo ou através do seu media, o que influencia necessariamente as suas escolhas e o seu comportamento jornalístico, bem como a sua abordagem ética da informação. Faz parte, por vezes infelizmente para ele, de uma elite, qualidade que o leva a entrar em relações de conivência com as diversas formas de poder, político, económico e social ${ }^{15}$. A estas relações sociais está associado um dos aspetos problemáticos da informação moderna: a atividade crescente dos profissionais da comunicação, relações públicas, adidos de imprensa, cuja função é fazer passar as mensagens favoráveis às instituições ou empresas que os contratam, controlar a informação que a eles respeita. Esta função é diferente da dos jornalistas, cuja referência única na escolha e no tratamento da informação é ou deveria ser o interesse público. Convém não ceder ao maniqueísmo: os profissionais da comunicação também são, em muito domínios, intermediários preciosos de informação. É portanto imposta aos jornalistas uma vigilância de todos os instantes, encarregados de velar por que aqueles não se tornem parasitas e não venham confundir a informação devida ao público.

e. O jornalista é um ator social e é também um sujeito moral. É dotado de subjetividade. Nas suas escolhas profissionais não pode fazer abstração da sua história pessoal, das suas origens sociais, do meio, da sua cultura, das suas convicções, das suas esperanças, dos seus desejos e dos seus receios. Estes parâmetros pessoais têm lugar na relação que o jornalista estabelece com a sua própria função social, com o exercício da palavra - o poder simbólico de participar na construção simbólica da imagem do mundo. O jornalista é, portanto, movido por outras forças para além da simples referência abstrata aos princípios da sua deontologia e aos valores que a orientam. Como se equilibram estas forças? Qual é, na relação com a autoridade prescritiva das normas, o encaminhamento da sua liberdade? É um debate filosófico imenso, permanentemente aberto, que é próprio de todo o indivíduo.

Ligando estes dois últimos aspetos, a psicologia social tenta identificar alguns destes parâmetros pessoais do jornalista na relação com o seu ambiente social. Um estudo conduzido nos Estados Unidos sobre os valores profissio-

${ }^{15}$ Ver os trabalhos de Rémy Rieffel, L'élite des journalistes. Les hérauts de l'information, Paris, PUF, 1984; e de Paul Beaud, La societé de connivence. Média, médiations et classes sociales, Paris, Aubier, 1984. 
nais dos jornalistas permite, desta forma, reter seis, que influenciariam principalmente a imagem que os jornalistas fariam das suas próprias responsabilidades: a idade e a experiência profissional, o nível de formação, a dimensão do meio de comunicação, o tipo de relação com os colegas de trabalho, o estatuto no seio da organização e o grau de integração na comunidade ${ }^{16}$.

f. As condições de produção dos jornalistas estão, para finalizar, cada vez mais submetidas ao imperativo da velocidade. Contra este determinismo tecnológico, o travão das regras profissionais parece inoperante, sob o efeito acelerador da concorrência. A velocidade é por vezes uma ferramenta fantástica e noutras vezes uma terrível limitação da informação. Ela é uma das causas principais - e provavelmente mesmo a causa principal - das negligências, dos erros, das escorregadelas dos jornalistas e dos media.

A velocidade, ao longo dos tempos, pesou sempre no processo da informação. Não é a notícia a única mercadoria que deixa de ter qualquer valor ao fim de 24 horas? Já no grande período da imprensa escrita, no século XIX e no início do século XX, tratava-se menos de "fazer informação" e mais de "a avançar, de a pôr em marcha, para finalmente a vender antes que esta se encontre literalmente ultrapassada” ${ }^{17}$.

O desenvolvimento dos media electrónicos acentuou o fenómeno a ponto de tornar problemática a colocação em prática de procedimentos de tratamento das fontes e a referência às regras normais da deontologia. É a informação que se deixou levar e não os acontecimentos, como por vezes se faz crer. E para além disso "a cobertura mediática do acontecimento incorpora-se no próprio acontecimento ${ }^{18}$. As técnicas de transmissão dos factos aceleraram-se até ao ponto inultrapassável da instantaneidade, do "direto". Elas asseguram, pela permanência do seu funcionamento e a multiplicação dos canais, um volume e uma intensidade jamais atingidas que tendem a escamotear os procedimentos de controlo reconhecidos pelas utilizações profissionais e exigidas pela deontologia. Como dar lugar a uma reflexão ética sob

\footnotetext{
${ }^{16} \mathrm{O}$ estudo global foi realizado a partir de 1300 entrevistas realizadas em 1971. John W. C. Johnstone, Edward J. Slawski e William W. Bowman, The news people: A sociological portrait of american journalists and their work, Urbana (III.), University of Illinois Press, 1976. Sobre a dimensão do meio de comunicação, ver também a distinção operada por Howard M. Ziff, "Practicing responsible journalism: cosmopolitan versus provincial models", in Deni Elliot(éd.), Responsible journalism, Beverly Hills/Newbury Park/London/ New Delhi, Sage, 1986, pp. 151--166.

${ }^{17}$ Paul Virilio, L'art du moreur, Paris, Galillée, 1993, p. 71.

${ }^{18}$ Jean-Claude Guillebaud, “Crise des médias ou crise de la démocracie?”, Le Débat, n. ${ }^{\circ}$ 66, septembre-octobre 1991, p.67.
} 
o constrangimento do determinismo tecnológico e sob a pressão do tempo, que nunca abranda?

Se a ética supõe a existência de um sujeito capaz de proceder a avaliações, a distinguir alternativas, a operar escolhas, de que liberdade usufrui ainda o jornalista encerrado nas limitações jurídicas, organizacionais e estruturais assim descritas? Esta liberdade parece bastante limitada. Ela não está em posição de desqualificar qualquer diligência ética: nem do ponto de vista de uma ética normativa, nem do ponto de vista de uma ética reflexiva que, interrogando as próprias condições da prática, procura identificar os constrangimentos a fim de agir sobre eles e de apurar as condições de uma "boa informação". A atividade jornalística é uma atividade enquadrada, não é uma atividade submetida.

As análises diferem sobre a margem de autonomia deixada ao jornalista. Sociólogos críticos, entre os quais os partidários mais radicais da abordagem sistémica, consideram-na como extremamente reduzida, em particular sobre o aspeto da investigação e do respeito da verdade na informação ${ }^{19}$. Isto tem por efeito diminuir a responsabilidade dos jornalistas como indivíduos e atribuí-la, proporcionalmente, aos media e mais ainda ao próprio sistema mediático no seu conjunto. As faltas do jornalista contariam pouco tendo em conta as falhas do sistema.

Esta visão pode ser reconfortante para a profissão, desculpabilizante. Mas torna evidente a contradição já assinalada entre a estigmatização constante, pelos jornalistas, dos constrangimentos aos quais eles estão submetidos e a importância de lhes garantir a liberdade que lhes deveria permitir aplicar a sua deontologia e assegurar a melhor síntese possível entre liberdade e responsabilidade ${ }^{20}$. A contradição é reveladora do aspeto estratégico da deontologia e dos seus instrumentos. Com menos peso efetivo face às questões estruturais, as normas desempenhariam então a função de álibi.

Esta visão é portanto insuficiente se se trata de responder aos atentados morais, reais, que se manifestam tanto entre os jornalistas como entre o

\footnotetext{
${ }^{19}$ Podemos citar a escola sociológica alemã que se reclama do pensamento de Niklas Luhmann, como Manfred Ruhl (Journalismus und Gesellschaft. Bestandesaufnahme und Theorieentwuf, Mayence, v. Hase und Koehler, 1980) e Ulrich Saxer ("Structurelle Möglichkeiten und Grenzen von Medien - und Journalismusethik", in Michael Haller et Helmut Holzey, éd. Medien-Ethik, Opladen, Westdeutcher Verlag, 1992).

${ }^{20}$ Esta contradição foi extremamente bem fundamentada e aprofundada por Boris Libois, Éthique de l'information. Essai sur la déontologie du journalisme, op. cit.
} 
público. É por isso que outros observadores colocam em evidência a capacidade de atuação dos atores no interior do sistema e descobrem espaços de liberdade, delimitados, mas suficientemente largos para que possam ser postas em jogo as responsabilidades éticas dos indivíduos ${ }^{21}$.

\section{Que responsabilidade para o jornalista?}

O feixe de normas, de restrições e de limites permite circunscrever a responsabilidade do jornalista enquanto indivíduo. A língua francesa reúne na mesma noção dois aspetos fundamentalmente diferentes, embora complementares. Ser responsável, é ser suscetível de responder por qualquer coisa. É igualmente responder perante alguém. A língua inglesa é, na génese, mais cómoda, distinguindo entre responsibility, que se reporta ao primeiro sentido da língua francesa, e accountability, que se reporta ao segundo ${ }^{22}$. De acordo com esta distinção, parece que os jornalistas são responsáveis, no que diz respeito ao conteúdo, por refletir de forma fiel e completa os assuntos públicos, por propor uma visão crítica, por assegurar uma informação com respeito pelos factos e pelas pessoas. Essa responsabilidade, simultaneamente individual e coletiva, cobre o conjunto dos deveres que se acordam impor ao jornalista nas diversas formulações da sua deontologia profissional.

O jornalista é igualmente o contabilista da sua informação. Ele é-o perante o seu público, em sentido lato, que legitima a sua atividade no seio da comunidade política. É-o perante a sua hierarquia, o seu chefe de redação, o seu editor, o proprietário do meio de comunicação para o qual trabalha. Pode ser chamado a prestar contas aos diversos poderes sociais, que esperam dele um comportamento que vá ao encontro das suas expetativas e à sua própria conceção da informação ${ }^{23}$.

Neste duplo sentido, a responsabilidade gera múltiplos conflitos internos: entre os diferentes deveres implicados pelo conteúdo (relevantes para a responsibility), entre as diversas obrigações impostas para com terceiros (relevantes para a accountability), e entre os deveres e as obrigações.

\footnotetext{
${ }^{21}$ Reclamando-se da abordagem sistémica e fazendo o inventário dos constrangimentos, Michael Mathien procura definir os aspetos desta liberdade.

${ }^{22}$ Esta distinção é claramente estabelecida por Louis W. Hodges, "Defining press responsibility: A functional approach”, in Deni Elliot (ed.), Responsible journalism, op. cit. Pp 13 ss.

${ }^{23}$ As relações de responsabilidade do jornalista no interior do seu medium, e do seu medium no interior da sociedade foram analisadas em duas figuras clássicas por Denis McQuail. Ver nomeadamente a sua conferência acerca da responsabilidade dos media que teve lugar na Universidade de Amsterdão em 7 de março de 1994.
} 
O jornalista não pode pretender atribuir a outrem a sua responsabilidade pessoal, no sentido de uma ética individual que não tenha em conta as condições e as consequências imediatas e restritas dos seus atos. Devido à própria mediatização das suas escolhas, que as multiplicam e ampliam, o jornalista é obrigado a fazer referência a um horizonte mais longínquo, no tempo e no espaço, que faz apelo ao "princípio da responsabilidade" tal como foi definido por Hans Jonas.

Através da natureza dos seus atos, os quais se inserem numa prática coletiva, o jornalista não poderá continuar a conduzir uma reflexão ética a sós. Ele deverá submetê-la a uma abordagem coletiva. Deverá ser uma reflexão em conjunto, em primeiro lugar no seio das redações e depois através de uma troca com o público. Passará igualmente por uma reflexão acerca das responsabilidades dos próprios media.

Tal deve-se à necessidade de ir para além do nível da simples deontologia profissional que apela à moral individual dos jornalistas, nível esse que se considera fundamental mas sobre o qual parece ter-se detido o debate da sociedade no que diz respeito à ética da informação. Esse aprofundamento deverá produzir-se na direção dos media enquanto organizações. Deverá igualmente produzir-se na direção da sociedade, conduzindo-a à interrogação sobre as expetativas do público em matéria de deontologia jornalística e, porque não, acerca das suas próprias responsabilidades éticas.

A evocação de normas, o inventariar de restrições, a observação de práticas, revelam a existência, no funcionamento do jornalismo, de um certo número de falhas que são indubitavelmente imputáveis aos jornalistas enquanto indivíduos. Surge igualmente um determinado número de defeitos, que são imputáveis às estruturas, às condições, ao contexto em que o jornalista exerce a sua profissão. Poderemos estabelecer uma enumeração? Parece possível identificar seis domínios particularmente sensíveis, em que alguns se referem aos elementos restritivos já mencionados ${ }^{24}$ :

- o enfraquecimento da independência dos jornalistas, por respeito às diversas formas de poder, político, económico ou social;

- a ausência de verificação ou confirmação da informação, sob os efeitos conjugados da concorrência, da ação dos comunicadores profissionais, da pressa;

${ }^{24}$ Refiro-me aqui ao modelo de grande interesse que está a ser desenvolvido pelos investigadores belgas do Observatório da narrativa mediática, restabelecido pelo Departamento de Comunicação da Universidade Católica de Lovaina. 
- a liberdade seletiva de acesso aos media, pela imposição de uma ordem do dia (agenda setting) que determina quais as informações dignas de serem divulgadas e quais os atores sociais que são chamados a exprimir-se, em detrimento dos mais fracos e das minorias;

- a encenação da informação, que incide quer sobre a escolha quer sobre o tratamento da informação;

- os atentados à liberdade individual e à vida privada, que tocam quer as pessoas que são objeto de informação, quer o próprio público quando se trata de difusão de imagens de violência ou de morte;

- a submissão dos agentes dos media às suas entidades patronais, que respondem a uma lógica económica, diversa da sua, e consequentemente a utilização da sua produção intelectual num sentido diferente daquele que os próprios the quiseram dar.

Estes seis domínios são cruzados por dois princípios comuns: por um lado, a investigação desinteressada da verdade e, por outro lado, a liberdade de expressão - frequentemente reduzida à sua correlativa, a liberdade de imprensa. Estes princípios transversais não têm o mesmo estatuto. A procura da verdade releva do conteúdo do trabalho jornalístico, logo da responsabilidade do jornalista relativamente a uma informação livre, que respeite os factos e as pessoas. A liberdade de expressão releva da função original da imprensa em democracia.

De acordo com a tónica que se colocar, na procura da verdade ou na liberdade de expressão, a imprensa revela disfunções que serão apreendidas como fraquezas ou enganos. Fraquezas no tratamento da verdade, enganos no tratamento da liberdade de expressão. Em qualquer dos casos, uns e outros relevam tanto, se não mais, de defeitos estruturais do que de falhas jornalísticas individuais. Ter isto em conta não significa que a ética dos jornalistas enquanto indivíduos esteja hoje ultrapassada, no sentido de que as normas da sua deontologia se tenham tornado inoperantes e obsoletas. Ter isto em conta significa que a abordagem individual da ética do jornalismo deverá ser objeto de uma ultrapassagem e que essa ultrapassagem deverá implicar a responsabilidade dos media enquanto organizações e como difusores de informação e a responsabilidade do público enquanto recetor de informação. 